\title{
Resisting Neoliberalism: Professionalisation of Early Childhood Education and Care
}

\author{
Mary Moloney ${ }^{1, ~ *, ~ M a r g a r e t ~ S i m s ~}{ }^{2}$, Antje Rothe ${ }^{3}$, Cynthia Buettner $^{4}$, Lisa Sonter ${ }^{2}$, \\ Manjula Waniganayake ${ }^{5}$, María-José Opazo ${ }^{6}$, Pamela Calder $^{7}$, Sarah Girlich $^{8}$ \\ ${ }^{1}$ Department Reflective Pedagogy of Early Childhood Studies, Mary Immaculate College, Limerick, Ireland \\ ${ }^{2}$ School of Education, University of New England, Armidale, New South Wales, Australia \\ ${ }^{3}$ Institut Für Sonderpädagogik University of Hanover, Hanover, Germany \\ ${ }^{4}$ Department of Human Sciences, Ohio State University, Columbus, United States \\ ${ }^{5}$ Department of Educational Studies, Macquarie University, Sydney, Australia \\ ${ }^{6}$ Faculty of Social Sciences, University of Nottingham, Nottingham, United Kingdom \\ ${ }^{7}$ School of Applied Science, London South Bank University, London, United Kingdom \\ ${ }^{8}$ Lakos, State Institute of Language Promotion in Early Childhood Education, Leipzig, Saxony, Germany
}

\section{Email address:}

mary.moloney@mic.ul.ie (M. Moloney)

${ }^{*}$ Corresponding author

\section{To cite this article:}

Mary Moloney, Margaret Sims, Antje Rothe, Cynthia Buettner, Lisa Sonter, Manjula Waniganayake, María-José Opazo, Pamela Calder, Sarah Girlich. Resisting Neoliberalism: Professionalisation of Early Childhood Education and Care. International Journal of Elementary Education. Vol. 8, No. 1, 2019, pp. 1-10. doi: 10.11648/j.ijeedu.20190801.11

Received: December 20, 2018; Accepted: January 29, 2019; Published: February 25, 2019

\begin{abstract}
Despite the relevance of early childhood services to children, families and nation states, the sector is largely undervalued and under resourced and, is not recognised as an established profession. Using collaborative auto ethnography, researchers from six different countries (Australia, Chile, England, Germany, Ireland and the United States) all members of the EECERA Professionalisation Special Interest Group (P-SIG) share their reflections on the professionalisation of early childhood. While professionalisation is associated with discretionary decision making that is premised upon an accepted body of knowledge, neoliberalism imposes constraints from on top, identifying through various forms of curricula, legislated standards, and policies what is appropriate and desirable practice. As a consequence, early childhood personnel are restricted in their professional agency and, their work is characterised by tension, as they strive to balance external expectations from a neoliberal stance and their own perspectives that prioritise a children's rights perspective. This paper questions how the sector manages the constraints imposed on it in a neoliberal political and social world. It calls upon those in the profession to resist neoliberalism and, to make a stand in terms of what is considered best practice. It further argues that ongoing debate is required as to the boundaries of what would be called the early childhood profession: considerations of ways in which the different sectors (education, health, and welfare) contribute to a holistic approach in working with children balanced against the requirement for a profession to have an identified and discrete body of knowledge. The implications of this for professionalisation of early childhood are widespread and, worthy of debate. While the inclusion of different sectors for example, addresses the holistic nature of early childhood work, it risks creating a broad and diffused knowledge base that might make it difficult to claim professionalisation. We hope that this paper contributes to reenergizing conversations on the professionalisation of the early childhood sector.
\end{abstract}

Keywords: Early Childhood, Neoliberalism, Auto-Ethnography, Reflections, Professionalisation

\section{Introduction}

The project upon which this paper is premised, arose from discussion at the 2017 European Early Childhood Education Research Association (EECERA) Conference Professionalisation Special Interest Group (P-SIG). 
Participants were engaged in vigorous debate around what the professionalisation of Early Childhood (the period from birth to eight years) meant and how best to pursue it. Discussion indicated that while professionalisation means different things to different people, participants agreed that early childhood generally is embedded in neoliberal agendas that hinder professionalisation. Although different nations develop and deliver early childhood services in different ways encapsulating different values and desired outcomes [1], it is widely recognised that the persistent devaluing and under-resourcing of the early childhood sector has hampered the advancement of the status and identity as a profession [24].

Accordingly, attempts to professionalise the sector prevail, in the expectation that professional status will result in enhanced quality of service delivery, and improvements in the conditions of employment, pay and status of those delivering these services [5-8]. However, the very diversity of contexts in which early childhood services are developed across nations impedes the evolution of the sector as a profession.

By its nature, a profession is expected to attain consensus around who should be included and excluded based on agreed common knowledge [2, 8-10]. Professional knowledge and practice are usually governed by principles in recognition of the impossibility of a standardized prescription for praxis [11, 12]. In other words, professionalism is inextricably linked with discretionary decision making [13-15]. This is a necessary feature of work in complex contexts [16] where each "situation can be distinctively different, and one-size-fits-all policies or procedures are deemed ineffectual" [8].

However, the expectations of professionalism clash with those evident in many nations where neoliberalism is influential in shaping not just the political arena but the very lives of citizens [17]. Against the backdrop of competing tensions between early childhood values, expectations of professionalism, neoliberal hegemonic oppression, competing aims, different political and social contexts, and different histories for the sector, the authors $(n=9)$ each of whom participated in the EECERA P-SIG share their professional reflections on what is needed to become an established profession that is recognised and valued by others.

This paper is presented in two sections. It begins with an exploration of neoliberalism, and the tensions between it and the early childhood sector by referring to market provision, externally defined standards of practice and regulation, the rights of the child and the accountability discourse and, finally, the purpose of education. Following a discussion of methodology, the paper presents analysis of participant reflections with regards to specialist knowledge, the diversity of the workforce, neoliberal perspectives on children and lack of professional agency resulting from neoliberalism.

\section{Exploring Neoliberalism}

Neoliberalism is described as "a mode of governance...one that produces subjects, ways of behaving, and organisation of social and economic life" [18]. It "sees competition as the defining characteristic of human relations" that:

Redefines citizens as consumers, whose democratic choices are best exercised by buying and selling, a process that rewards merit and punishes inefficiency. It maintains that "the market" delivers benefits that could never be achieved by planning [19].

Basically, neoliberalism constructs models of actions which are based on the principles of the economic arenas, extended to other areas which have been excluded before, such as education or health systems [20].

In the realm of early childhood, private for profit provision has been used by Governments to promote service expansion [21]. The assumption being that private places will materialize more quickly and flexibly than can be provided by the State, and that quality can be achieved through competition, and through regulation [22]. It is also assumed that:

1. Competition among service providers will drive down prices and increase quality;

2. The market will sort itself out more efficiently than any regulatory intervention.

Thus, parents are constructed as consumers, and early childhood services as a commodity to be bought; early childhood services become just another product on the market Underpinning this positioning is the claim by [23] that neoliberalism has become so hegemonic in many national contexts that it is "accepted as the only possible economic and social order available to us" (p.258) and thus, it shapes "our language, our understanding of the choices we face and our conception of ourselves" [17]. Moreover, the impact of neoliberalism has:

Seduced people into chasing commodities, and infantilised them through the mass production of easily digestible entertainment, disposable goods, and new scientific advances in which any viable sense of agency was undermined. The conditions for critical thought dissolved into the pleasures of limited gratification wrought through the use of technologies and consuming practices that dampened, if not obliterated, the very possibility of thinking itself [24].

The relevance of this to the early childhood sector is profound [25] and enacted differently across different nation states.

\subsection{Neoliberalism and Early Childhood Personnel}

Externally defined standards of practice are a feature of early childhood in many countries. In Australia, for example such standards (supported by a federal accreditation system) against which the work of early childhood personnel (ECP) is evaluated, result in a judgement that, if found wanting, can have significant financial consequences for the service [26, 27]. Accompanying these standards in Australia is a new educational leader role designed to 'educate' ECP into compliance with the standards. Similarly in Ireland, standards are externally determined by the Child and Family Agency: TUSLA the national agency for registering and 
inspecting all early childhood services. In addition, the Department of Education and Skills (DES) undertakes inspections of services participating in the Early Childhood Care and Education (ECCE) schemei. In Ireland therefore, ECP is underscored by robust accountability and is rigidly policed. Overall, externally defined quality standards such as exist in Australia, Ireland, England and Chile for example, position ECP as technicians in the manner identified by Moss [28] with a consequent loss of discretionary decision-making $[14,29,30]$. Furthermore, as studied by Roberts-Holmes [31] in England, these kinds of robust accountability systems within early childhood have led to a datafication of early childhood education.

In other nation contexts similar actions are identified as de-professionalisation e.g., [5, 32-35] which positions this approach as the right of the neoliberal state to "manage and influence the behaviours of individuals in order to ensure they make the 'right' choices" [36] However, the effectiveness of a highly regulated system is debatable. For instance, while tracking undertaken by the Australian Children's Education and Quality Authority (ACECQA) the national quality assurance agency in Australia and by TUSLA in Ireland, has resulted in increasing levels of complianceii it is posited that "performing 'quality' actually involves the homogenisation of settings towards common 'outcomes' or quality indicators" [37, p. 41]. Consequently, a 'good' service becomes one that best addresses the government's economic agenda rather than one that best supports the rights of young children and their families [38]. The tension between these two positions (attempting to ensure improvements in quality through the creation of national standards, national curricula and quality assurance processes, and the expectation that professionalism is defined by discretionary decision-making) remains unresolved.

\subsection{Neoliberalism and Children's Rights}

A second tension between neoliberalism and the professionalisation of early childhood is connected with how children are perceived. Although early childhood is commonly underpinned by a children's rights perspective [39], it has been suggested that this rights agenda has been high-jacked by neoliberalism and turned into a children-ashuman-capital (investment for the future) discourse [14, 37, 38]. Hence early childhood services are justified on the basis of their potential to ameliorate disadvantage and enhance human capital development $[1,40]$. Nation States therefore focus upon accountability, intertwined with the discourse of outcomes, investment and value for money.

A robust accountability system is based upon the "standardised test-making industry" [41 p.8] as evidenced through the introduction of the International Early Learning Study (IELS) a cross-national assessment of early learning outcomes involving the testing of children between 4.5 to 5.5 years in 3-6 participating countries initially (Organisation for Economic Cooperation and Development (OECD) [42]. Ultimately, testing of young children results in the 'schoolification' of early childhood education [43]. In the
United States for example, which pursues a market-oriented approach to quality assurance, State and national governmental agencies define quality and use these definitions as a way to educate parents as consumers with the aim of having the market drive improvements to care settings and ultimately, to children's school readiness [44].

None the less, economic evidence provided by Heckman [45] for example, alongside support for the human capital position by key agencies (e.g., United Nations Educational Scientific and Cultural Organisation (UNESCO)), creates a strong basis for recognising the importance of the work undertaken by ECP with young children and families. Moreover, as noted by Ring, Mhic Mhathúna, Moloney et al., [46] in a context where school teaching is considered to be more valued and as having more status than early childhood employment, it is not surprising that many ECP acquiesce to the education-discourse positioning of their work. Yet, this positioning undermines key elements of early childhood ideology relating to children's rights, and the concomitant requirement to value children for who they are right now rather than for the compliant neoliberal citizens they are being educated to become [25]. Here we draw upon Urban and Swadener [47] who refute testing of children in early childhood, noting that.

It actively contradicts the rights of children, families and communities to meaningful participation in all matters concerning and affecting the upbringing and education of young children. (p. 12)

Furthermore, Moss [48] contests the notion that early childhood services should be understood as a business, and a place to apply technologies to children to achieve predetermined goals and readiness for school. Rather, he argues that they should be viewed as a public space and place of encounter for all citizens.

\subsubsection{Neoliberalism and the Purpose of Education}

There is of course another key tension between neoliberalism and early childhood ideology - the perceived purpose of education itself. In some nations, early childhood was (and in some cases still is) underpinned by a child development perspective focused on enabling children to achieve their potential. This particular perspective underscores the developmentally appropriate practice movement in the U.S [49, 50] within which the achievement of developmental milestones is considered a good indicator of children's wellbeing [51].

Such holistic perspectives encompass much more than a range of developmental domains (i.e., physical, social and emotional well-being) but in a number of contexts these understandings were later married with bio-ecological and/or sociocultural perspectives [52] to create a life-course, contextual focus. More recently, this expanded focus has identified key desired outcomes for children: namely health and nutrition, security and safety, responsive caregivingiii, positive early learning experiences and the provision of enabling environments for caregivers, families, and communities [53-56]. 
This holistic focus emphasises the aim of early childhood services as creating contexts where children's lives today (with the focus on now, the present) are positive, caring and rich in appropriate learning experiences. Conversely, as indicated, the primary aim of neoliberal approaches to early childhood services is to create the neoliberal citizen of the future. Shaping early childhood services in this latter manner, results in a "pedagogy of ignorance whose hidden curriculum is the teaching of political and intellectual conformity" [24]. In other words, early childhood services are contributing to the creation of "job ready zombies" [57]. For many, the increasing downward pressure of reading, writing and mathematics into early years' curricula (a process known as schoolification) is a symptom of neoliberal positioning [58].

\section{Methodology}

Following the 2017 EECERA, P-SIG, ten participants (9 of whom are co-authors of the present paper) representing six countries: Australia, Chile, England, Ireland, Germany and the United States, decided to share their reflections on professionalisation, as a means of influencing debates about professionalisation of early childhood. In so doing they accepted an interpretive ontology as defined by Lin [59] whereby they recognised that while each is an active researcher in the early childhood sector, reality is different for each member. Their social constructivist epistemology positioned their reflections as their own individual 'truths' arising from each person's experiences in the Early Childhood sector. Informed by symbolic interactionism, they shared their 'truths' with each other through the English language.

This paper arose therefore from a collective autoethnographic process using professional reflections which start with personal reflections, a "process of self-exploration and interrogation aids individuals in locating themselves within their own history and culture and allowing them to broaden their understanding of their own values in relation to others" [60]. Furthermore, Rappaport, [61] suggests that collaborative auto-ethnography "shifts control of the research process from the hands of the anthropologist into the collective sphere of the anthropologist working on an equal basis with community researchers" (p. 6) where different forms of knowledge are combined through a process of interaction [62]. Consequently, collective auto-ethnography is liberatory, in that reflection on personal experiences creates the space whereby participants can "move from where they are to where they want to be" [63].

Figure 1 illustrates the conceptual framework for the study which was developed from the literature and identifies the contextual factors impacting on early childhood professionalisation as the ways in which EC ideology and neoliberalism play out in different national contexts.

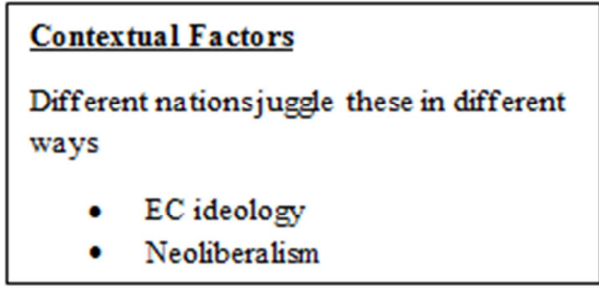

\section{Opportunities}

- What does a dult education have to offer?

- Collective action

- Self-governance

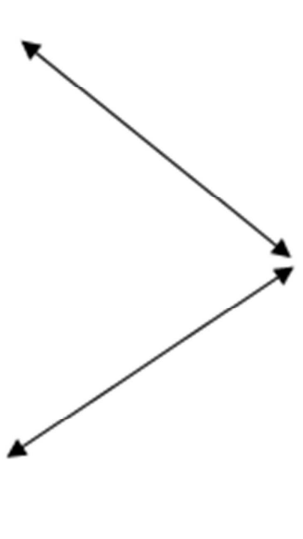

Challenges

- Definition of a profession

- Diversity of the sector

- Positioning of children

- Professional agency/discretionary

Figure 1. Conceptual Framework.

As discussed earlier, this inter-play creates challenges to professional agency, the way in which children are positioned and the aim of education.

\subsection{Method}

Based upon their lived experience in the early childhood sector, P-SIG participants were asked to reflect upon the following question: What is needed to become an established profession that is recognised and valued by others? A brief description of the research process and the estimated time commitment, was circulated to all on the P-SIG list. Those who chose to do so responded with their professional reflections. The P-SIG conveners read through each of the ten reflections received, and requested participants to further develop their reflection. All transcripts and analysis was circulated to the group for member checking (more details below). A draft paper was crafted and circulated to participants thus facilitating further reflections which were subsequently analysed and incorporated into a second draft paper for a final consultation. All participants involved in these discussions became the authors of this paper which was co-constructed through the data collected and analysed. 


\subsection{Analysis}

Initial data analysis was aligned with the thematic areas included in the conceptual framework (Figure 1) which involved multiple readings of reflections to identify the emerging themes using a process of constant comparison as originally defined by Glaser [64]. Further analysis helped to identify themes not captured in the initial conceptual framework. This iterative process occurred on receipt of the first round of reflections, and on receipt of reflections arising from the first drafted paper. All data analysis was undertaken by more than one member of the team ${ }^{\text {iv. }}$

\subsubsection{Research Rigour}

Rigour in auto-ethnographical research is best addressed through establishing credibility [65]. In the present study, this was addressed through member checking, also known as participant validation [66]. As mentioned, analysis of reflections, drafts of the research paper, and the final write up of the paper were circulated to each of the participants to check for accuracy and resonance with their experiences. Additionally, themes were triangulated by reference to extant literature.

\subsubsection{Ethics}

Although it is commonly accepted that autoethnographical research is not subject to scrutiny through university Ethics Committees [67], adherence to ethical procedures is essential. At the outset, each participant was aware of the voluntary nature of participation, and that they could withdraw at any stage without reason or consequence. Each time reflections, analysis and draft research papers were circulated, "process consent" [68] was used to check that participants still wished to be part of the study. It was also agreed at the outset that while the P-SIG conveners would lead the study, each participant would have full agency through-out the process in terms of refining or adding to reflections, undertaking data analysis and contributing to the various drafts of the research paper. In this way, participants had "a path toward personally engaging, non-exploitative, accessible research" [67].

\section{Results}

\subsection{Specialist Knowledge}

In considering what is needed to become an established profession that is recognised and valued by others, participants started from a sociological understanding of the early childhood profession. They determined that a key element of professionalisation is that the sector has status which is recognised by others outside the profession, and is strongly related to a specialist knowledge base upon which members of the profession draw. P2 (from the U.S) writes.

A profession obtains its status...to a large degree from having a knowledge base that is socially recognised by other relevant actors participating in the field (ie government, families) as the highest knowledge available within its respective area of specialisation. This means that a profession represents the ultimate authority, the most trustworthy source of theoretical principles that can be translated into practice.

Accordingly, participants agree that special knowledge is a core aspect of professionalisation and.

Composed of capabilities and skills that are justified scientifically or rationally, it is complex and inaccessible to lay persons, and is acquired in special institutions of advanced education (usually in universities). In addition, this knowledge base has rules, formal procedures and attitudes regarding its application ( $P 2$ ).

Concurring with this perspective, P8 (from Ireland) notes that "professionals command a body of technical expertise that is not shared by those outside the profession." P3 (from Australia) agrees:

a specialist body of knowledge that can be deemed discipline specific and that those who are seeking membership in the EC profession must complete 3-4 years of study at a university to learn and understand this requisite knowledge and skills.

Equally, P9 (from England) articulates how a profession must be associated with " $a$ body of expertise that takes years to acquire, that it is specialised and difficult and also develops its own specialised terminology..."

Reiterating the need for specialist knowledge P2 (from the U.S) suggests:

The indefinite borders of EC teachers' knowledge base has been identified as a major limitation to obtain professional recognition. Certainly the multiplicity of profiles present around the world suggest a lack of consensus on the professional role of EC teachers that dilutes the specificity of their specialisation

Alongside the need for specialist knowledge acquired through lengthy study (as articulated by P9 from England, P3 and P4 from Australia), participants highlight the importance of the professional autonomy which they suggest characterises a profession, noting in particular, the profession's "claim to autonomy in decision making" (P2 from the U.S). Participants point to obstacles that hinder the profession to fulfil these characteristics and gain full recognition of society. Speaking about the U.S., P2 writes "Childcare workers average pay is less than the pay of those who care for non-farm animals". Drawing upon research she has undertaken on ECE teachers' stress, she describes how:

In the focus groups we conducted ...we talked about how people who interact with them view what they do. They talked about some parents treating them with disrespect, about their own family members and acquaintances not valuing what they do-referring to them as babysitters.

A similar situation prevails in Chile, with $\mathrm{P} 7$ writing that "society sees. [ECP]. more as caregivers, or nannies, rather than professionals of children's pedagogy". She suggests that the low pay within the sector is associated with perceptions of the work as just playing with children, "an early childhood educator therefore, performs an easy job. In a way, since it is an easy job, the bad salary is justified and it seems fair 
enough".

\subsection{Diversity of the Early Childhood Workforce}

In addition to reflecting upon the knowledge base, participants considered whether all professionals within the same profession need to hold the same knowledge, or can there be differences? In the German context, P1 suggests that the different discipline backgrounds of ECP make it difficult to identify common knowledge. P10 also from Germany agrees, noting that " $a$ wide range of qualifications exists in the sector". Both refer to an emerging trend in Germany to modify the traditional and common vocational training to an academic qualification. In common with P2 (from the U.S) and P7 (from Chile) they express concern with regards to remuneration of ECP, observing that "the higher qualification is still not reflected in professional salaries".

In Chile professional knowledge is obtained through an undergraduate degree where expert knowledge is learned including "the national curriculum, pedagogy, children's learning and reflective practice" ( $\mathrm{P} 7)$. The similarities across reflections is noted by P3 who finds it "fascinating how similar many of the things you talk about are to our experiences here in Australia". P4 also from Australia agrees, stating that "qualifications vary which adds more complexity". Pointing to the education/care debate which is perceived differently in across different contexts, $\mathrm{P} 3$ suggests that further difficulties arise as "the salaries and working conditions of Australian ECP with identical qualifications differ depending on the ECEC sector in which they are employed". Adding to the debate, P7 is clear that in Chile, "early childhood educators are professionals from the field of education." In contrast, P3 from Australia asks: "Who is part of this EC profession? In the global north there is a strong education focus so that in Australia EC professionals are EC teachers/educators".

P6 (from Australia) argues for a focus on "EC development" rather than "EC education". She articulates how:

$E C D$ is multi-sectoral and includes health workers, family support workers, EC educators, child protection workers, social workers and community workers. When they are working with young children and their families do we include them in the EC profession?

Referring to the German context, P10 acknowledges the broad focus in Saxony, as well as in other Federal states on "children's health and well-being" but she continues to position the EC profession inside "the day care system." In contrast, P9 notes how in England some of the direct face-toface work with children has been replaced by family support which inevitably changes the nature of what we understand to be the early childhood profession:

They have turned centres into hubs, some even virtual hubs, and no longer require them to provide any direct support to women and children in the form of early -childhood - care and - education - daycare. Instead they are exhorted to be coordinating centres of outreach, or part-time parenting programmes, parenting advice, stay and play, baby yoga etc.
She advocates for "one core graduate profession to work in early childhood education and care". This does not mean that there should not be:

other professional graduate workers, in health or social work for example, that should be available to be called in for specialist advice... workers in centres that integrated care and education would all need the same basic required graduate knowledge and skills and qualifications but could be provided with specialist options (P9).

In their reflections, participants problematize the difficulty in identifying a common knowledge for the EC sector which is complicated because of its association with that of mothering and a similar relationship with caring work in general. P9 identifies the concerns:

If we say that graduates are necessary to look after their children then we are implicitly making the case that mothers and fathers should also be graduates or else be at risk of not being seen as worthy of looking after their own children.

P8 (from Ireland) argues that caring professions tend to be highly gendered as caring itself is perceived as women's work. "It generally follows that women's work is undervalued, particularly when it is perceived in terms of love and care, rather than serving a crucial role in society". Concurring with this perspective, P2 (from the U.S) suggests: "it's tied up in how "women's work" is devalued, how making lots of money is pointed to as how one is measured as "successful". The role of the higher education system in terms of progressing professionalisation features in the reflections of P4 (from Australia): "requiring professional education be delivered through the higher education system to help move perceptions towards professionalism". However, in the absence of valuing care, relationships and women's work more broadly, P9 argues that higher education will not succeed. She asserts that such an effort must be included in a process where we "revalue care, relationships, [and] women's work more generally." None-the-less, P4 posits that:

Rigorous and lengthy training helps to sustain the status of the profession, and the members are protected by professional bodies (e.g., medical council), enjoy economic rewards commensurate with their qualifications and experience, as well as autonomy and self-governance.

P3 (from Australia) concludes that the professionals' contract and (therefore) the knowledge base is specific. The contract is not a technocratic enterprise and this should be reflected in the specificity of the knowledge base. She suggests putting the child "at the core of decision making" and to rely on internationally valid sources like the UN convention.

\subsubsection{A Neoliberal Perspective on Children}

P10 holds that the children's rights perspective in Germany has gradually changed, replaced by an academic focus, partly because of poor PISA results in 2000. Likewise, P7 summarises the various elements of this perspective contextualised within Chile:

Even though there is a commitment towards children's right to education, there is also underlying ideas and images 
of nurseries and preschools as places which are preparing children for the future ... Early childhood education is seen as an opportunity to decrease inequality and lack of social justice by giving to children the tools to 'success' later on in their school trajectories

P1 concurs and traces this in the development of services in Germany suggesting that internationally "there is a dominant trend of viewing EC in economic terms". As a consequence of this positioning, she identifies a move towards 'schoolification'.

Reflecting upon the role of ECP in Australia, P3 stresses the importance of "acting with and advocating for children and families, responsive to their context, making informed decisions based on specialised knowledge and skills." Clearly signifying an alternative to neoliberalism, she goes on to define the early childhood profession as, ideally:

Not an industry, it does not produce a product ... a sociocultural view of ECEC services where the child is at the core of decision making in which educators work with others to draw on a range of skills, knowledge, experience and professional judgement to best support the child. These measures differ for each child and numerous diverse approaches may be taken for one child.

\subsubsection{Lack of Professional Agency}

As indicated previously, participants identify discretionary decision-making as a key element of working with children and hence of professionalisation. P2 (from the U.S) identifies this as "professional authority within a specialty, claim to autonomy in decision-making". She also identifies the importance of holding power over decision-making: "within the workplace and within communities, EC professionals would not be relegated to the powerless position".

In the German context P1 discusses the lack of involvement of ECP in defining quality practice, "members of the ECEC profession are rarely involved". She argues that there is value in including ECP voices as they are more closely aligned to early childhood ideology than they are to neoliberalism. Accordingly, members of the profession have the potential to provide balance in the debate:

The ECEC workforce strongly represents the whole child approach despite growing competing tendencies in the scientific debate. It could help to involve these voices in the debate (P1).

P5 (from Chile) agrees: "These aspects should not be defined by government agencies ...rather come from members of the profession." Whereas in England, P9 indicates that "teachers have become state regulated, not self-regulated." Likewise in Germany, P1 suggests "there is a strong tendency to tell early childhood professionals what to do" She scorns attempts in Germany to adopt what she and P6 from Australia term "an audit culture". P1 therefore indicates that "Even an audit culture comparable to the ECEC system in the UK seems to be attractive for some", hence ECP "are positioned as passive receptors of training" (P10 from Germany). In Ireland, P8 suggests there is a "tendency for government to dictate every aspect of what practitioners do". In the Australian context, P6 refers to the fear associated with this kind of audit culture, particularly in terms of noncompliance with legislative standards:

The extent to which EC staff or settings are aware and understand their discretionary powers is difficult to know as the fear of non-compliance resulting in a breach takes control of everyone concerned

Commenting on early childhood in Australia, P3 supports this perspective, writing that many ECP:

seek a right way of performing to these standards [National Quality standards] in order to meet the highest level ... so while these documents seek to challenge educators and services to respond to their local context, many educators are caught up in finding templates, resources and quick 'fixes' which do little to support the idea of children as individuals and educators as able to make professional decisions.

And the effect of this technicist approach upon childrens' learning experiences in early childhood services? Regrettably, from the perspective of $\mathrm{P} 3$, it seems that children themselves too, are reduced to conformists, such that:

In many services there is still a lot of evidence of children all completing the same activity or tasks, or all documentation being similar. So, the significance of the child as an individual can get lost as some services focus on mass produced documentation or whole group instruction

\section{Discussion}

Havnes [10] suggests that professionalisation is driven from the top by policy and research which is transmitted to practitioners through pre-service and in-service training and, then applied by practitioners in their daily work with young children and families. Given that all authors of this paper are active researchers in the sector, and some are involved in the education of future and/or current practitioners, their understandings of professionalisation which have been shaped by their research and practice, have some impact on debates around the professionalisation of early childhood.

While reflections identify the importance of a shared body of knowledge, what should be included in that body of knowledge is unclear, primarily due to the diversity of the workforce within each country which challenges the practicality of that knowledge being held within one generic professional being. The Nurturing Care Framework released by the World Health Organisation and the United Nations International Children's Emergency Fund [69] identifies early childhood work as including children's health and wellbeing, nutrition, responsive caregiving, security and safety and early learning opportunities which are considered an equal, not more important, priority [53-55, 70]. This framework indicates the need for cross sectoral work. It clearly positions early education as an element of early childhood work, but not the only element: a challenge to the focus in much of the western world on early education. In fact early education with its focus on testing young children, is central to neoliberal perspectives which propose that 
appropriately prepared neoliberal employees are shaped through education. Given that school teaching is perceived as being more valued and as having more status than early childhood employment, it is not surprising that many ECP acquiesce to the education-discourse positioning of their work [46]. At the same time, the elements of early childhood work not commonly accepted as part of the education discourse, particularly work with babies and toddlers are at risk of being lost should professionalisation be pursued solely through the education discourse [6]. It is therefore heartening to note that alternative discourses are being explored through initiatives such as the Nurturing Care Framework [69] that may gain prominence across nations in the future.

We are concerned about how the early childhood sector manages the constraints imposed on it in a neoliberal political and social world. As reiterated throughout this paper, a core aspect of professionalisation relates to discretionary decision making by practitioners, with decisions being made based on an accepted body of knowledge. Conversely, neoliberalism imposes constraints from on top; identifying through various forms of curricula, legislated standards, and polices what is appropriate and desirable practice. As mentioned, early childhood practitioners thus become technicians, implementing required procedures with children and families [14, 28-30] where even those in leadership positions are increasingly likely to focus on shaping those they supervise into what is identified as correct practice [27]. Our reflections clearly identify the tension between these two extremes and our concern about how this tension plays out in the desire for increasing professionalisation. In the interests of furthering the professionalisation of the early childhood sector, we ask whether ECP should resist neoliberalism within which parents are constructed as consumers and early childhood services as a commodity to be bought.

\section{Conclusion}

Professionalisation of early childhood requires those in the profession to make a stand in terms of what is considered best practice. Of course this is dependent upon the capacity of ECP to challenge the top down policy directives that underscore early childhood ideology and practice. A key question for us as authors is: 'how we can equip current and future ECP to withstand these directives and advocate for what is best for children, i.e., learning through play?' ECP must also ask what is best for the sector. Viewing education in its broadest sense, and not just in terms of 'schoolification' [43] or datafication [31] opens opportunities to consider other disciplinary backgrounds, and therefore other types of specialist knowledges.

As our reflections indicate, ongoing debate is required as to the boundaries of what would be called the early childhood profession: considerations of ways in which the different sectors (education, health, and welfare) contribute to a holistic approach in working with children balanced against the requirement for a profession to have an identified and discrete body of knowledge. The implications of this for professionalisation of early childhood are widespread and, worthy of debate. For example, while the inclusion of different sectors addresses the holistic nature of early childhood work, it risks creating a broad and diffused knowledge base that might make it difficult to claim professionalisation. In raising this and other issues throughout this paper, including qualification levels and duration of initial preparation, we hope that it contributes to reenergizing conversations on the professionalisation of the early childhood sector.

\section{References}

[1] Roopnarine, J. L., Johnson, J., Quinn, S., \& Patte, M. (2018a). International perspectives on early childhood education. In J. L. Roopnarine, J. Johnson, S. Quinn, \& M. Patte (Eds.), Handbook of international perspectives on early childhood education (pp. 1 - 10). New York and London: Routledge.

[2] Moloney, M. (2015). Untangling the knots - [k]not easy. Professional identity in the early childhood care and education Sector. A paper prepared for the symposium, Early Educational Alignment: Reflecting on Context, Curriculum and Pedagogy.

[3] Moloney, M., \& Pope, J. (2015). Where to now for early childhood care and education (ECCE) graduates? A study of the experiences of Irish BA ECCE degree graduates. Education 3-13, 43 (2), 142-152.

[4] Pramling Samuelsson, I., Kulti, A., \& Pramling, N. (2018). Conceptualizing early childhood education and care for a global community. New directions for policy initiatives. In J. L. Roopnarine, J. Johnson, S. Quinn, \& M. Patte (Eds.), (Eds.). (2018). Handbook of international perspectives on early childhood education. New York and London: Routledge. (pp. 423 - 429). New York and London: Routledge.

[5] Osgood, J. (2010). Reconstructing professionalism in ECEC: The case for the "critically reflective emotional professional". Early Years: An International Journal of Research and Development, 30 (2), 119 - 133.

[6] Sims, M., Alexander, E., Nislin, M., Pedey, K., Tausere-Tiko, L., \& Sajaniemi, N. (2018). Infant and toddler educare: a challenge to neoliberalism. South African Journal of Childhood Education, 8 (1), 1 - 8.

[7] Sims, M., Alexander, E., Pedey, K., \& Tausere-Tiko, L. (2018). What discourses relating to the purpose of early childhood are shaping the work of early childhood practitioners in three different contexts: UK, Bhutan and the South Pacific? Journal of Education and Learning, 7 (2), 223 - 236.

[8] Waniganayake, M., \& Sims, M. (2018). Becoming critically reflective: Australian educational leaders effecting change as street-level bureaucrats In A Neoliberalist Policy Landscape. In J. L. Roopnarine, J. Johnson, S. Quinn, \& M. Patte (Eds.), Handbook of International perspectives on early childhood education (pp. 230 - 247). New York: Routledge Press.

[9] Ashcraft, K., Muhr, S., Rennstam, J., \& Sullivan, K. (2012). Professionalization as a branding activity: Occupational identity and the dialectic of inclusivity-exclusivity. Gender, Work \& Organization, 19 (5), $467-488$. 
[10] Havnes, A. (2018). ECEC professionalisation - challenges of developing professional standards. European Early Childhood Education Research Journal, 26 (5), 637 - 673.

[11] Griffiths, M., Brooks, D., \& Corkill, J. (2010). Defining the security professional: Definition through a body of knowledge Paper presented at the Proceedings of the 3rd Australian Security and Intelligence Conference Edith Cowan University, Perth, WA.

[12] Rogers, W., \& Ballantyne, A. (2010). Towards a practical definition of professional behaviour. Journal of Medical Ethics, 36 (4), $250-254$.

[13] Evans, A. (2010). Professional discretion in welfare services: beyond street-level bureaucracy. Burlington, VT: Ashgate.

[14] Sims, M., Waniganayake, M., \& Hadley, F. (2017). Educational leadership - an evolving role. Educational Management, Administration and Leadership, 20 pages downloaded.

[15] Moloney, M., \& McKenna, I. (2017). Is it time to establish an early years council? Education Matters Year Book.

[16] Lipsky, M. (2010). Street level bureaucracy: Dilemmas of the individual in public services. 30th Anniversary Expanded Edition New York, NY The Russell Sage Foundation.

[17] Monbiot, G. (2017). Out of the wreckage. A new politics for an age of crisis. London: Verso.

[18] Vintimilla, C. D. (2014). Neoliberal fun and happiness in early childhood education.

[19] Monbiot, G. (2016). Neoliberalsim - the ideology at the root of all our problems. The Guardian, April 15, 8 pages downloaded.

[20] Walkerdine, V., \& Bansel, P. (2010). Neo-liberalism, work and subjectivity: Towards a more complex account. In M. Wetherell \& C. Talpade Mohanty (Eds.), The SAGE Handbook of Identities (pp. 492-507). London: SAGE Publications.

[21] Lloyd, E., \& Penn, H. (2012). Childcare markets: Can they deliver an equitable service? Bristol: Polity Press.

[22] Penn, H (2012). Childcare markets: do they work? in eds E. Lloyd and H. Penn (2012) Childcare Markets: Do They Deliver an Equitable Service. Bristol. Policy Press, 19-42.

[23] Davies, B., \& Bansel, P. (2007). Neoliberalism and education. International Journal of Qualitative Studies in Education, 20 (3), $247-259$.

[24] Giroux, H. (2015). Dangerous thinking in the age of the new authoritarianism. Boulder, CO: Paradigm Publishers.

[25] Sims, M. (2017). Neoliberalism and early childhood. Cogent Education, 4, 1365411.

[26] Sims, M., Mulhearn, G., Grieshaber, S., \& Sumsion, J. (2015). Australian national ECEC reforms, with a focus on the national quality framework and the national quality standard. Expert report for the German Youth Institute. Munich: Deutsches Jugendinstitut e. V (German Youth Institute).

[27] Sims, M., \& Waniganayake, M. (2015a). The performance of compliance in early childhood: Neoliberalism and nice ladies. Global Studies of Childhood, 5 (3), 333 - 345.

[28] Moss, P. (2006). Structures, understandings and discourses: possibilities for re-envisioning the early childhood worker. Contemporary Issues in Early Childhood, 7 (1), 30-41.
[29] Rouse, E., \& Spradbury, G. (2016). The role of the educational leader in long day care - how do they perceive their role? Early Child Development and Care, 186 (3), 497-508.

[30] Skattebol, J., Adamson, E., \& Woodrow, C. (2016). Revisioning professionalism from the periphery. Early Years, $36(2), 116-131$.

[31] Roberts-Holmes, G. (2015). The 'datafication' of early years pedagogy: 'if the teaching is good, the data should be good and if there's bad teaching, there is bad data'. Journal of Education Policy, 30 (3), 302-315.

[32] Chalke, J. (2013). Will the early years professional please stand up? Professionalism in the early childhood workforce in England Contemporary Issues in Early Childhood, 14 (3), 212 - 222.

[33] Cooke, G., \& Lawton, K. (2008). For love or money: Pay, progression and professionalisation in the 'Early Years' Workforce. London: Institute for Public Policy Research.

[34] Hulme, R., McKay, J., \& Cracknell, D. (2015). From commissar to auctioneer? The changing role of directors in managing children's services in a period of austerity. Educational Management Administration \& Leadership, 43 (1), 77 - 91.

[35] Oberhuemer, P. (2005). Conceptualising the early childhood pedagogue: Policy approaches and issues of professionalism. European Early Childhood Education Research Journal, 13 (1), 5-16.

[36] Furedi, F. (2017). What's happened to the university? A sociological exploration of its infantilisation. Abingdon, Oxon: Routledge.

[37] Hunkin, E. (2016). Deploying Foucauldian genealogy: Critiquing 'quality' reform in early childhood policy in Australia. Power and Education, 8 (1), 35-53.

[38] Hunkin, E. (2017). Whose quality? The (mis)uses of quality reform in early childhood and education policy. Journal of Education Policy, 33 (4), 443-456.

[39] Sims, M. (2015). Social justice, children's needs and rights: an approach to planning. Journal of Curriculum and Teaching, 4 (2), $122-129$.

[40] Vandenbroeck, M, Lenaerts, K and Beblav ý. (2018). Benefits of early childhood education and care and the conditions for obtaining them. EENEE Analytical Report No.32. Prepared for the European Commission.

[41] Pinar, W. (2011). Allegories of the present: Curriculum development in a culture of narcissism and presentism. Paper presented as part of the Pinar Seminar Series 2011-2012, University of British Columbia, Vancouver, Canada.

[42] Organisation for Economic Co-operation and Development. 2016. Call for tenders: International Early Learning Study.

[43] Pardo, M., \& Woodrow, C. (2014). Improving the quality of early childhood education in Chile: Tensions between public policy and teacher discourses over the schoolarisation of early childhood education. International Journal of Early Childhood, 46 (1), $101-115$.

[44] Schaack, D., Tarrant, K., Boller, K., \& Trout, K. (2012). Quality rating and improvement systems: Frameworks for early care and education systems change. In S. L. Kagan \& K. Kauerz (Eds.), Early childhood systems: Transforming early learning (pp. 71 - 86). New York: Teachers College. 
[45] Heckman, J. (2014). Going forward wisely. Paper presented at the The White House Summit on Early Education, Washington D. C.

[46] Ring, E, Mhic Mhahuna, M, Moloney, M, Hayes, Breatnach, B et al. (2016). An examination of concepts of school readiness among parents and educators in Ireland. Dublin: Department of Children and Youth Affairs.

[47] Urban, M, and Swadener, B. B. (2017). Democratic accountability and contextualised systemic evaluation. A comment on the OECD initiative to launch an International Early Learning Study (IELS). International Critical Childhood Policy Studies Journal, 6 (1), 6-18.

[48] Moss, P. (2013). Beyond the investment narrative. Contemporary Issues in Early Childhood, 14 (4), 370 - 372.

[49] Centre on the Developing Child. (2014). Enhancing and practicing executive function skills with children from infancy to adolescence.

[50] Johnson, J., \& Patte, M. (2018). United States perspectives on early childhood care and education. In J. L. Roopnarine, J. Johnson, S. Quinn, \& M. Patte (Eds.), Handbook of International perspectives on early childhood education (pp. 379 - 391). New York \& London: Routledge.

[51] Fernald, L. C. H., Prado, E., Kariger, P., \& Raikes, A. (2017). A toolkit for measuring early childhood development in lowand middle-income countries. Retrieved from Washington DC.

[52] Edwards, S. (2009). Early childhood education and care: a sociocultural approach. Castle Hill, NSW: Pademelon Press.

[53] Black, M. M., Walker, S. P., Fernald, L. C. H., Andersen, C. T., DiGirolamo, A. M., Lu, C., . for the Lancet Early Childhood Development Series Steering Committee. (2017). Advancing early childhood development: from Science to Scale 1. Early childhood development coming of age: science through the life course. Lancet, 389, 77 - 90.

[54] Britto, P. R., Lye, S. J., Proulx, K., Yousafzai, A. K., Matthews, S. G., Vaivada, T., Bhutta, Z. A. (2017). Nurturing care: promoting early childhood development. Lancet, 389 (10064), 91-102.

[55] Sims, M., \& Brettig, K. (2018). Early childhood education and early childhood development - do the differences matter? Power and Education, 0 (0), 1 - 13.

[56] Moloney, M., \& McCarthy, E. (2018). Intentional leadership for effective inclusion in early childhood education and care. London: Routledge.

[57] Hil, R. (2015). Selling students short. why you won't get the university education you deserve. Crows Nest, NSW: Allen \& Unwin.

[58] Brogaard Clausen, S. (2015). Schoolification or early years democracy? A cross-curricular perspective from Denmark and England. Contemporary Issues in Early Childhood, 16 (4), 355-373.

[59] Lin, A. (2015). Researcher positionality. In F. Hult \& D. Cassels Johnson (Eds.), Research methods in language policy and planning: a practical guide (pp. 21 - 32). Malden, MA: John Wiley \& Sons Inc.

[60] Starr, L. (2010). The use of autoethnography in educational research: Locating who we are in what we do. Canadian
Journal for New Scholars in Education: Revue canadienne des jeunes chercheures et chercheurs en éducation, 3 (1), 9 pages downloaded.

[61] Rappaport, J. (2008). Beyond participant observation: Collaborative ethnography as theoretical innovation. Collaborative Anthropologies, 1, 1-31.

[62] McCabe, M., \& Cultural Connections LLC. (2014). Collaborative ethnography: Intersection of knowledge, power and emotion. International Journal of Business Anthropology, $5(1), 11-17$.

[63] Boughton, B. (2013). Popular education and the 'party line'. Globalisation, Societies and Education, 11 (2), 239 - 257.

[64] Glaser, B. (1965). The constant comparative method of qualitative data analysis. Social Problems, 12 (4), 436 - 445.

[65] Le Roux, C. S. (2017). Exploring rigour in autoethnographic research. International Journal of Social Research Methodology, 20 (2), 195-207.

[66] Birt, L., Scott, S., Cavers, D., Campbell, C., \& Walter, F. (2016). Member checking: a tool to enhance trustworthiness or merely a nod to validation? doi: 10.1177/1049732316654870.

[67] Lapadat, J. C. (2017). Ethics in autoethnography and collaborative autoethnography. Qualitative Inquiry, 23 (8), 589-603.

[68] Ellis, C. (2007). Telling secrets, Revealing lives. Relational ethics in research with intimate others. Qualitative Inquiry 13 (1), 3-29.

[69] World Health Organisation and United Nations International Children's Emergency Fund. (2018). Nurturing care for early childhood development. A global framework for action and results. Consultation document.

[70] Richter, L., Daelmans, B., Lombardi, J., Heymann, J., Lopez Boo, F., Behrman, J. R., with the Paper 3 Working Group and the Lancet Early Childhood Development Series Steering Committee. (2017). Investing in the foundation of sustainable development: pathways to scale up for early childhood development. The Lancet, 389 (103 - 118).

i First introduced in 2010, the ECCE Scheme provides early childhood care and education for children of pre-school age. From September 2018, children can start ECCE when they are 2 years and 8 months of age and continue until they transfer to primary school (provided that they are not older than 5 years and 6 months at the end of the pre-school year).

ii For information relating to Australia, see for example ACECQA's Quarterly Snapshots available on the agency website https://www.acecqa.gov.au/nqf/snapshots, and for Ireland, see https://www.tusla.ie/uploads/content/Tusla_EYI_annual_report_MASTER_2017. pdf

iii The term caregiving is used in preference to parenting in recognition that not all children are cared for by their parents

iv In presenting the analysis, a different font is used to identify quotes from the data in order to differentiate these from quotes sourced from the literature. 